\title{
AN UNUSUAL CASE OF LARYNGEAL SYPHILIS REQUIRING TRACHEOTOMY.*
}

BY CLEMENT F. THEISEN, M.D., ILEANY, N. Y.

The following case, because of several rather unustial features, was considered worth putting on record.

Mrs. J., aged 38 years, married, consulted the writer for the relief of a gradtually increasing difficulty in breathing. This she had noticed for nearly a year, and on any exertion, like walking up stairs, great dyspnoea always came on.

There was, at the time the patient consulted the writer, a well marked respiratory stridor, and the inspiratory thrill, which is characteristic of laryngeal stenosis, could be felt when the fingers were placed over the region of the larynx. Her first husband contracted syphilis, and also developed a pulmonary tuberctulosis, of which he died. The patient's family history, however, is negative in this respect, there having been no cases of tuberculosis so far as known.

The patient herself was inoculated with syphilis by her first husband some years ago, and received a thorough course of treatment. At that time, there were well marked constitutional symptoms, with necrosis of the bone in several of her toes, necessitating some operative work. No symptoms of laryngeal obstruction developed until about a year before the writer was consulted, and since then, as before stated, there had been an increasing difficulty in breathing.

On examination, the nose and naso-pharynx, with the exception of a slight naso-pharyngeal catarth, were found practically normal. Patient had a slight chronic pharyngitis. The tonsils were not enlarged. The uvula was slightly elongated and thickened, and was infiltrated for about one half its length from the tip. This portion of the uyula was very hard to the touch. There was no ulceration, nor any eviclence of former ulceration.

The entire epiglottis was infiltrated, its surface being perfectly smooth however, and it was also extremely firm to the touch. It was pulled back to such an extent, that the laryngeal entrance was practically closed, and the only way a laryngeal examination could be made, was by pulling up the epiglottis after cocainization. The .

* Read at the Eleventh Annual Meeting of the American Laryngological. Rhinological and Otological Socicty, Boston. June, 5, 1905. 
epiglottis was also free from ulceration. This peculiar position of the epiglottis is probably due to old lateral syphilitic adhesions. There is considerable resistance when the epiglottis is pulled up in making a laryngeal examination. The aryepiglottic ligaments appear thickened and shortened.

On laryngeal examination, a most interesting state of affairs was found. The glottis, with the exception of a very small opening posteriorly, was closed by a mass of cicatricial tissue stretching from side to side, just under the vocal cords. This was found to be extremely dense and unyielding when examined with a probe. Practically no changes in any other part of the larynx could be seen. The movements of the arytenoids were somewhat impaired, the result probably of an old'perichondritis.

A careful physical examination of the patient was made by an excellent general practitioner who found her lungs normal. $\mathrm{He}$ found a right movable kidney and a digestive disorder, otherwise the patient was found to be in a fair general condition.

The sputum was examined several times with negative results. The patient was told that her laryngeal condition was serious, and consented to remain in the hospital for a time. A piece of the infiltrated epiglottis was removed and sent to the Bender Laboratory for examination. The report stated that the piece removed showed simply a chronic inflammatory process. No tubercle bacilli were found in sections of the removed tissue.

Iodide of Potash was administered, in order to see what effect it would have on the infiltrated uvula and epiglottis. The uvula became decidedly thinner and softer, but no change in the epiglottis could be determined.

The administration of the Iodide however, brought on a sudden. attack of laryngeal oedema; with greatly increased dyspnoea, and it was then promptly stopped. Preparations for performing tracheotomy were made, but the oedema subsided so quickly, with proper local measures, that it was not required.

As the patient did not desire any further operations at this time, she was discharged from the hospital, but was kept under constant observation. During the succeeding few months, she got along fairly comfortably, when she did not exert herself in any way, but finally, when attacks of dyspnoea became more frequent, she consented to a tracheotomy.

She was again admitted to the hospital and a low tracheotomy performed. A general anesthetic was not used on account of the great laryngeal obstruction, but the operation was performed with 
a solution consisting of equal parts of a $1 / 2$ per cent.cocaine and a I-IO,000 adrenalin chloride solution, making a solution of $1 / 4$ per cent cocaine, and I-20,000 adrenalin.

In a discussion upon the fatal results of operations upon the nose and throat, (in the transaction of the Amercan Laryngological Association for $1904^{3}$,) I called attention to the value of this solution in performing tracheotomies. It should be put up under aseptic precautions, preferably the day of the operation, and the bottle kept under a I-I,O00 solution of bichloride, until the solution is drawn into a sterile hypodermic syringe after the patient's neck is prepared for the incision. It is only necessary to inject a few minims at different points along the line of incision. It is an ideal solution for tracheotomies in adults. I mean of course in cases in which the patient is in no immediate danger of death, so that the operator can take his time.

The use of a general anesthetic in cases where there is some form of laryngeal obstruction, - and that is usually the condition for which a tracheotomy is performed,-is not safe. In emergency cases, where the patient is in imminent danger of death, the operator would of course not lose time in using any anesthetic at all, either general or local, nor could a local anesthetic of this kind, be used, in performing tracheotomies upon children or very nervous adults. It should be only used in selected cases. The addition of even such a weak solution of adrenalin chloride to the cocaine solution, has distinct advantages, as it assists in preventing the possible unfavorable effects of the hypodermic injection of cocaine.

The writer's patient complained of very little pain during the operation, and it certainly adds very materially to the comfort of the operator, if he is able to take his time in performing a tracheotomy.

The further history of this case, is of no great interest perhaps, except that the gain in the patient's general condition has been quite remarkable.

At the time of the operation she was much reduced, and since then she has gained over thirty pounds in weight. She is still wearing the tracheotomy tube, and will probably continue to do so for some time. She has been told that a radical operation, consisting of a thyrotomy, with a careful removal of the cicatricial tissue, followed by intubation, might, relieve the breathing to such an extent, that she would be able to permanently discard the tube. Up to the present time, however, I have not been able to get her consent, as she is so well satisfied with her condition. There is 
no way of dilating this stricture from above, as the cicatricial tissue is so absolutely myielding.

The question as to just what to do in such severe cases is an interesting one. We must always be prepared to perform tracheotomy, and must bear in mind a statement of Simpson's "that all cases of laryngeal or tracheal stenosis however gradual, may at any. moment take on a sudden exacerbation." The proper method of getting ricl of the laryngeal stenosis after tracheotomy, is of great importance.

J. Payson Clark² has reported an interesting case of probable syphilitic stenosis of the larynx, in a young adult, on whom a tracheotomy had been performed for increasing dyspnoca. Dr. Clark was umable to pass'intubation tubes, so while the patient was under ether, the tracheotomy tube was removed, and gradually larger sizes of female urethral sounds were passed through the tracheal opening and up into the larynx. A pair of long narrow slightly curved forceps was then passed up through the tracheal opening and througl the glottis. The intubation tube was put on the forceps, which was then pulled back through the tracheal opening until the intubation tube was properly adjusted. The patient however unfortunately coughed out the tube, and as he would not consent to have it reinserted the tracheotomy tube had to be put back, when he left the hospital. This method would probably not be applicable to cases of syphilitic stenosis, in which, as in the writer's case, the cicatricial tisste practically occlucles the glottis, and is so clense. The patency of the glottis would first have to be restored by removing this tissue by a laryngo-fissure, after which this method would undoubtedly be very useful.

In cases of simple syphilitic stenosis of the larynx, caused by infiltration and thickening of the corcls and ventricular bands, or perichondritis with oedema of the mucous membrane, intubation with gradually larger tubes, preceded in all severe cases by a tracheotomy, is, I believe, the best treatment.

The writer has had several cases of this sort, on one of which the stenosis was in the trachea, well below the glottis, and could be finally dilated with Schrötter's tubes.

A preliminary tracheotomy in severe cases of syphilitic stenosis of the larynx should be performed perhaps in the majority of the cases. Then the operator can work from above, without the danger of an attack of sudden oedema, and asphyxiation of the patient.

There are many cases of syphilitic stenosis of the larynx on record, in which tracheotomics had to be performed for increasing 
or sudden alarming dyspnoea. I will not take your time in considering them in detail.

Such cases have been reporterl by, Jeanne", Leonardi', Navratil", $\operatorname{Descos}^{10}$, Stein ${ }^{10}, \mathrm{Hall}^{10}$, Clark*, Woods ${ }^{1 \mathrm{~s}}$, Spencer ${ }^{8}$ and others. In the cases reported by these authors, the stenosis was caused by infiltration and thickening of the vocal cords, and ventricular bands, and not by cicatricial tissue stretching between the cords.

In a fairly careful search of the literature of the past ten years, not many cases were found, in which the stenosis was produced by cicatricial tissue occluding the glottis by uniting the cords, or extending across the trachea.

Cases of this kind have been reported by Bleyer ${ }^{17}$, Moritz" Collinet $^{13}$, Echtermeyer ${ }^{-14}$, Heymann" and Hubbard ${ }^{12}$. In Hubbard's case the diagnosis of syphilis was not absolutely positive. I was only able to find a few reports of cases in which the peculiar position of the epiglottis, closing the laryngeal entrance was present.

Naviatil ${ }^{15}$ and Zwillenger ${ }^{11}$ have reported such cases.

Bleyer ${ }^{17}$ has reported eight cases of syphilitic stenosis of the larynx caused by a web formation. They were operated on by his combined method of tubage and the knife. He first cut through the membranous formation with Lenox Brown's sharp dilator, and then quickly dilated with intubation tubes.

In Hall's case of syphilitic stenosis, a tracheotomy had to be performed, and the patient died after conghing out the tube.

In Moritz' case, there were adhesions uniting the cords, in a young woman, aged 24 years. A tracheotomy was performed.

Collinet has reported a case of syphilitic stenosis of the larynx, in which cicatricial tissue took the place of the cords and ventricular bands.

In Echtermeyer's case, there was a membrane uniting the cords and almost closing the glottis. A tracheotomy was performed. after which the membrane was removed, and intubation practiced until the patency of the larynx was restored.

In a case reported by Spencer, the stenosis was caused by the presence of firm irregular masses of tissue, which covered the vocal cords and ventricular bands. This was removed by thyrotomy.

In Descos' case, a tracheotomy was performed for extreme dyspnoea, and later a laryngo-fissure was made, and the soft parts of the larynx resected. There were no adhesions in this case.

Navratilis has reported two cases, in which, tracheotomy had t.) be performed for laryngeal stenosis caused by syphilis. 
Heymann ${ }^{5}$ has reported a number of cases in which membranous adhesions existed in the larynx. He cloes not give the exact number of cases.

In a case recorded by Sargnon ${ }^{4}$, daily intubation had to be performed before the stricture was permanently dilated.

Navratil ${ }^{20}$ and Z willinger $^{11}$ have reported cases in which the epiglottis was pulled back, (as in the writers case), to such an extent, that the laryngeal entrance was closed.

In Zwillinger's case, there were adhesions between the epiglottis and aryepiglottic folds. In Hubbard's case ${ }^{12}$ a thyrotomy was performed and the membrane uniting the cords removed.

\section{CONCLUSIONS. .}

a. Intubation is particularly useful in the cases in which the stenosis is not extreme, and when it is caused by a thickening and infiltration of the cords and ventricular bands, thus narrowing the glottis.

In some such cases, intubation may be carefully used without perhaps preliminary tracheotomy.

b. When the stenosis is extreme, or when membranous adhesions exist between the cords, leaving only a very small opening, a tracheotomy should precede attempts to dilate the stricture from above. It is in such cases that a sudden oedema may be fatal before an intubation tube could be properly adjusted.

c. Tracheotomy, followed by laryngo-fissure, offers the best chances of a permanent cure, when there is much cicatricial tissue occluding the glottis by uniting the cords.

I72 Washington Ave.

BIBLIOGRAPHY.

1 Simpson, W. K. A Study of the Proper Application of Intubation. Tr. Am. Laryngol. Ass., 1901.

2 Clark, J. Payson. Rapid Dilation and the Prolonged Use of Intubation Tubes. Tr. Am. Laryngol Ass., 1902.

3 Packard, F. A. A Study of the Fatal Results of Operations upon the Nose and Throat. Tr. Am. Laryngol. Ass., 1904.

4 Sargnon. Un Cas de Syphilis Laryngec Tertiaire chez un Adult, etc. Ann. d. mal. de l'oreille, du larynx; Paris, No. 7, July, 1896.

5 Heymann, P. Ueber Verwachsungen $\mathfrak{u}$. Verengerungen im Rachen $\mathfrak{u}$. Kehlkopf, infolge von Lues. Deutsche med. Wchnschr. Leiprig, No. $30,1895$.

6 Jeanne. Syphilis du Larynx. Bull. Soc. de med. de Ronen, Nov. 12, 1900. 
7 L_conard, Z. I. Report of a Case of Specific Laryngeal Stenosis. N. I: Eye and Ear Infirm. Rep., Jan., 1901.

8 Spencer. Report of a Case of Tertiary Syphilitic Stenosis of the Laryux. Tr. London Laryngol. Ass., Nov. 1, 1901.

9 Navratil. Ber. cl. Gesellsch, d. Ungar. Ohren u. Kehllkopf Aerzte. Oct. 23, 1902.

10 v. Stein, S. F.. Hosp.-Tid., Kjobenh., 1901, p. 601.

11 Zwillinger. Ber. d. Gesellsch, d. Ungar. Ohren u. Kehlkopf Aerzte. Jan. 24, 1901.

12 Hubbard, Thos. A Case of Multiple Laryngo-Tracheal Stenosis. Tr. Sec. Laryngol, and Otol., A. M. A., 1899.

13 Collinet. Rep. French Ass. of Otol, and Laryngol., Oct. 19, 1903.

14 Echtermeyer. Ber. (l. Berl. Laryngol. Gesellsch., Jan. 22, 1904.

15 v Navratil. Ber. d: Gesellsch. d. Ungar. Ohren u. Kehlkopf Aerzte. Jan. 28, 1899.

16 Descos. Retrecissement Syphilitique d. Larynx. Soc. d. sc. med. de Lyon. June, 1899.

17 Bleyer, 'J. M. Eight Cases of Syphilitic Stenosis of the Larynx, etc. Joum. Am. Mled. Ass., Nov. 25, 1893.

18 Woods, R. H. Case of Tertiary Syphilis of the Larynx. Lancet, May 19, 1894.

19 Hall, de H. Tr. London Laryngol. Ass., March 14, 1894.

20 v. Navratil. Tr. Otol. and Laryngol. Soc. of Budapest, Jan. 25, 1894.

21 Moritz. Agglutination of the Vocal Cords." Brit. Medl. Journ., March 23,1895 .

Two Cases of Abnormal Mobility of the Tongue-M. DELSAUx.Rev. Hebd. de Laryngol. d'Otol. et de Rhinol., July 23, 1904.

On account of the rarity with which such cases are met,. Delsaux, of Brussels, reports two cases which presented abnormality in the mobility of the tongue. These patients could pass the point of the tongue above the velum palati into the naso-pharyngeal space. The motion of the tongue forward was also more than usual. He finds only six such cases reported in medical literature.

(Probably such cases are not as rare as Delsaux seems to believe, because the majority of them are not recorded. The reporter knows of two similar cases in which the patient could pass the tongue into the naso-pharynx. One of them relieved himself from the annoyance of a chronic naso-pharyngitis in this manner. Scheppegrell.) 